\title{
FEATURES OF INTERACTION BETWEEN THE STATE AND CIVIL SOCIETY IN THE CONTEXT OF THE PHILOSOPHY OF LAW
}

\begin{abstract}
The article explores the notion and peculiarities of the concept of "civil society" in the modern, legal state. In the given research, the author implements a holistic, systematical (methodical) analysis of peculiarities of the relationship between the state and society. Therefore, the theoretical and practical research of problems of development of the relationship between civil society and the state gives an opportunity to find new solutions in problems of cooperation of individual and shared interests. Moreover, the study is also focusing on various approaches of well-known jurists on the essence, content and legislative consolidation of civil society.

The author concludes that in recent decades, the philosophy of law took under its active protection the civil society, where the harmonious combination of rights, freedoms and legitimate interests of the person should correspond to public interests. Therefore, the theoretical and practical analysis of interactions between the state and civil society allows finding new solutions to problems that occurred in modern society.
\end{abstract}

Keywords: civil society, democratic legal state, fundamental rights and freedoms of the individual, government, citizen, organizations, institutions, political life.

\section{Introduction}

In the modern philosophy of law, there are numerous approaches to the concept of "civil society". First of all, the concept of "civil society" is based on the ancient Roman term "civitas" (from civis - citizen), which denoted the concept of the civil community whose members (the Romans) were subjects of Roman civil law (ius civile). Second, the terms "civitas", "civis", "ius civile" had a syncretic meaning, without distinguishing between their political and non-political meanings. Subsequently, the legal and political meaning was preserved in the term "citizen", and the non-political meaning in the term "civil society", "civil law" (Lagutkin, Trubnikov, \& Grudtsyna, 2013, pp. 4-6).

Sometimes, in the works of ancient philosophers, the concept of "civil society" was used to characterize the existing social and state systems. Plato and Aristotle reveal the idea and essence of the concept of "civil society" in ancient Greece, where there was a social stratum of citizens who had the right to form state power.

Plato was the first ancient philosopher who identified (revealed) the elements of civil society within the framework of his general theory of the "ideal state", in which he criticized state power and created the doctrine of the "ideal human society". Moreover, the four cardinal Platonic virtues: wisdom, courage, moderation, and justice, were fundamental to "civil society" (Kolesnikova \& Ryabova, 2016, pp. 7-8).

According to Aristotle, citizens are the foundation of civil society. The state is obliged to educate citizens in moral virtue to strive for a "happy life". At the same time, citizens should perform a military function in their youth and their old age - actually political. In this approach to the capabilities of citizens, there is an entirely meaningless attitude: wise citizens in old age are able and obliged to determine the rights of those 
who, as a citizen, begin to "serve" society. The essence of this idea can be formulated as follows: the power represented by the state determined the rights of citizens.

In the Middle Ages, based on the writings of Aristotle, Thomas Aquinas considered the concept of civil society from the point of view of society, in which people exercise their natural rights, and divine laws prescribed by God guides the formation of human laws. Therefore, Jesus's admonishment: "Thou shalt love thy neighbour as thyself' creates the prerequisites for the development of a society where people's rights and legitimate interests are respected and where laws adopted apply equally to all citizens (O'Brien, 1999).

A particular approach to the concept of civil society was in the Age of Enlightenment, in the works of Th. Hobbes, J. Locke, Ch. Montesquieu and other famous thinkers, philosophers.

Th. Hobbes considered that the purpose of the state is to protect society and the state. In this system, the principles of civil society are poorly expressed. In its turn, J. Locke argued that the state's power should be limited to the basic, inalienable rights of the citizen, such as the right to life, liberty, and property.

$\mathrm{Ch}$. Montesquieu justified the rule of law and formulated the concept of freedom, which is the right to do anything that is not prohibited by law. According to Ch. Montesquieu, civil society is the fourth stage in the development of human history, after the natural state, the family, and the society of the heroic time. Society is based on civil and political laws. Civil laws are the inalienable rights of members of society, and political laws are the laws of civil society but transferred to the state. Therefore the state, with the help of these laws, restricts the fundamental rights and freedoms of the individual.

It should be noted that an significant contribution to the disclosure of the concept of civil society was made by G. Hegel, who determined that civil society reflects the phenomenon, the scope of private interest. According to Hegel, ci- vil society is formed when people unite on the basis of trade and money, based on ties determined by individual interests. An individual, without a relationship with others, cannot achieve the full scope of his goals. In its turn, the state must ensure the realization of citizens' general interest; therefore, it is a higher stage of development of society and stands above civil society (O’Brien, 1999).

\section{Analysis of Interaction Between the State and Civil Society}

The analysis of the concept of civil society confirms that clarification and legal regulation of relations between civil society and the state in a modern democratic, legal state are of paramount importance since they determine the formation of the political system, state and public institutions of the state.

According to the universally recognized definition, civil society is a relatively independent and self-organizing system of social, economic and political relations that includes various forms of associations of people in order to meet their own material and spiritual needs. Moreover, in such type of public life, the individual citizen is the core value, the main functioning subject and the final end with his/her interests, requirements and rights (Bolleyer, 2019, p. 22; Marchenko, 2014, pp. 553-554).

The conducted research shows that contemporary civil society includes social-political institutes independent of the state, reflecting a wide variety of social interests in the social, legal, political and spiritual spheres of personal life.

Therefore, H. Hovhannisyan (2016) rightly pointed out that within a democracy, the civic society is a mode of organizing public life characterized by: 1) a vast network of non-governmental structures formed voluntarily (unions, associations, organizations); 2) a comprehensive system comprising economic, political, social, spiritual, cultural relations (p. 98).

The civil society aims to achieve an optimal 
and harmonious combination of private and public interests.

In the theory of modern state and law, there are two approaches to defining the concept of "civil society". In one case, "civil society" is considered as a set of social structures and relations that are not directly regulated by the State. In another case, "civil society" is presented as the foundation of society at every stage of the development of a democratic, legal state.

N. Mikhalkin (2019) rightly pointed out that in the modern philosophy of law, the need for the existence of civil society is determined by such factor as the distinction between human rights and civil rights, where human rights are provided by civil society and the rights of citizens-by the rule of law (pp. 320-322). Moreover, in recent years, many legal scholars have interpreted the term "law" in the context of philosophical liberalism, which does not reflect the content of the culture of human existence that has actually been formed in the world (Marzik, 2013, pp. 11-12). Therefore, if we turn to the contents of such legal systems as the RomanoGermanic and Anglo-Saxon, it will be found that there are different limits of manifestation of rights and freedoms, both for a person and for a citizen.

The study of the peculiarities of the functions of the state in the judicial literature is associated with the study of the peculiarities of civil society, and vice-versa: the study of the peculiarities of civil society is joined with the study of the peculiarities of the state. Therefore, the research of these issues and the comprehensive studies are undoubtedly crucial for revealing the peculiarities of both civil society and state institutions.

The conducted research shows that due to the strenuous activity of the state and elements of the political system in a particular historical period, fundamental preconditions are created for the formation of civil society. Moreover, some legal scholars argue that in this case, the state and civil society should not be opposed to each other, since at a certain level of self-organization of the political life of society, favourable conditions are created for the formation of a legal state.

It is evident that the self-government of the society exists due to the system of the state and civil society. In addition, the state and civil society are the results of the historical development of humanity. It is known that the necessary condition for the emergence and formation of civil society is the citizens' private property and economic, social, legal, and political independence. Therefore, the priority is the manifestation and realization of the integrity of human rights (Kochatkov, 1994).

We agree with the opinion of several post-soviet researchers that the basic purpose of the formation of the new society is the formation of public and state institutions, civil society (Ryabev, 2005).

Furthermore, in the modern judicial literature, civil society is also characterized as a sphere of spontaneous self-expression of organizations and associations formed by citizens, where the necessary laws protect the activities of these citizens from illegal interference of state bodies. Moreover, civil society is a specific type of society based on the principle of justice, where a person can achieve the highest good.

It should be noted that in the modern philosophy of law, the concept of "civil society" is connected with the terms "good society" and "prescriptive state".

First of all, the term "good society" is mainly used to refer to societies built on a moral foundation, infrastructure (such as family, school, community, etc.) and in which informal social control operates to form a core of substantial moral values.

Second, the term "prescriptive state" is used to refer to states that rely heavily on coercive means to enforce such moral values and that have an extensive list of values that they seek to impose on society (Etzioni, 2000, pp. 360-362).

It should be noted that the problem of the formation of civil society is defined by the formation and development of numerous structural 
forms of the political system of society, which are based on political, legal, economic and social relations between the state and the person. Concurrently, its emergence is due to the formation of institutions capable of self-organization and self-development, which are necessary to ensure a decent and prosperous life for citizens. Obviously, in the age of globalization, democratic processes take place in various spheres of public life and create specific prerequisites for the development of self-governing institutions. Consequently, the conditions for the formation of civil society, the social activity of people constitute mechanisms for expressing and implementing their shared interests, which regulate public relations.

Civil society forms a kind of sphere of activity and relations between citizens, which unites the organizations and institutions created by them, objective laws, opportunities, and structures of their formation. Moreover, in the process of forming the system of relations between the state and civil society, the boundaries of the political, economic, and legal activities of citizens and social groups are also important, as well as their behaviour, which gives a certain direction to the integral system of society, forming the core of political life.

It is noteworthy that A. Hayek (1990), considering the relationship between the state and civil society in the context of the liberal approach, notes that the state should not interfere in the development of civil society, since in this case, the well-known slogan "laissez-faire" loses its true meaning, undermining the principles of liberal politics.

Therefore, the study of this problem makes it possible to identify the fundamental origins of political and legal processes, as well as their socio-legal functions.

A. Aleksanyan (2006) rightly pointed out that in specific historical conditions, the system of public interests and needs establishes several regularities, characteristics of the activities of public institutions and citizens (p. 312). At the same time, the involvement of members of society in political life, their interests, expectations for the future are characterized by the relations between public institutions, and political attitude to state institutions.

Meanwhile, there is an opinion in judicial literature that civil society is a society where a person is guaranteed by law a free choice of economic and political life, securing his universal rights (Smolkov, 1991).

In our opinion, forming a legal system of relations between public and state institutions allows for the emergence and active interaction of various subsystems of political power in society. The activities of non-governmental organizations and citizens in creating a unique model of civil society are emphasized. Such a model of civil society ensures the organization of the political life of society, structural and functional stability, creation of a new system of relations between the state and the person.

In the modern philosophy of law and political science, there are three possible options for cooperation between the state and civil society (Abakumov, 2005, pp. 32-38):

1. civil society and the state are partners,

2. civil society and the state act as parties to the conflict,

3. civil society and the state act independently of each other.

The first version of cooperation is the best because only as a result of such relationships can we build a strong, sovereign, democratic, social state governed by the rule of law. Moreover, this relationship method has been implemented in the states of continental law, where the relationship between the state and the citizen tends to be on the same scale, complementing each other. As for the second option, such relations are found in almost all transition countries, where people with a low level of legal awareness prevail. Due to certain factors, civil society and the state act as opposite institutions to each other, and in this case, the state restricts the basic human rights, freedoms and legitimate interests. In turn, civil 
society has an extremely negative attitude towards the functioning of the state and its institutions, even being ready for a revolution.

It should be noted that in a real, democratic, legal, social state, civil society and the state are interrelated and complement each other. In this case, the state exercises the interests of the majority of people, and civil society assists the state in this matter.

Meanwhile, in a democracy, civil society and the state coexist harmoniously, i.e., the state expresses the interests of the majority of the population, and the civil society, as a rule, contributes to the state in all matters.

In the third case, we face a situation where the civil society and the state are independent of each other and have almost no contact points, which is less possible in the current conditions of globalization.

Considering the interaction models between civil society institutions and state authorities, we can also underline examples of cooperation between the state and non-profit organizations in post-Soviet countries.

The modern theory of state and law identifies three models (three roles) that non-profit organizations can assume, depending on whose interests prevail: performing functions arising from the interests of the authorities, fulfilling social obligations delegated by the authorities, solving acute social problems. At the same time, it should be taken into account that any interaction between public organizations and structures of state authorities directly depends on the political regime of the country (Kolesnikova, 2013, pp. 270-271; Volkov, 2011, pp. 24-25). Under a dictatorship, civil society institutions struggle for human rights and freedoms, and in this case, their independence is directly related to the lack of state funding. Therefore, we agree with $\mathrm{H}$. Hovhannisyan (2016) that in such a case, these organizations play the role of "the fifth wheel of the cart" in public administration (p. 98).

In our opinion, since many institutions of civil society in European countries and the United
States are financed by the state, for the development of a genuine civil society in transition countries, it is essential that these institutions could refuse such aid, through which the state can dictate its terms to the civil society.

\section{Conclusion}

Summing up the results of explored issues and considering civil society as a dynamic phenomenon of philosophy of law, we concluded that it is necessary to consider the interaction between the state and civil society in the frame of social, economic and political processes of the society and state. It is known that the emergence of civil society is due to the recognition of the individual, personal freedom of every person, which is reflected in the corresponding prerequisites. Consequently, modern civil society provides an opportunity for the person to develop as an independent being, at the same time considering the individual in universal unity, in the whole state-society system. Therefore, the individual, special interests and aspirations of the people must be conformed to the common interests of the society and the state.

As a result of our research, we have come to the simple conclusion that for the origin, development and effective operation of civil society, not only state-independent political and non-governmental organizations are needed, but also the opportunity for effective cooperation with all branches of government.

\section{References}

Abakumov, S. (2005). Grazhdanskoye obshchestvo i vlast': protivniki ili partnery? (Civil society and power: Opponents or partners? (in Russian)). Moscow: Galeriya.

Aleksanyan, A. (2006). Qaghaqaciakan hasarakut'yun (Civil society, in Armenian). Yerevan: YSU.

Bolleyer, N. (2019). The State and Civil Society. 
Oxford: Oxford University Press.

Etzioni, A. (2000). Law in civil society, good society and the prescriptive state. Chicago-Kent Law Review, 75(2), 355-377.

Hayek, A. (1990). Doroga k rabstvu (The Road to Serfdom, in Russian). Voprosy filosofii (Questions of Philosophy, in Russian), 11, 121-129.

Hovhannisyan, H. (2016). Idea and models of civil society: Development, tendencies, arguments pro and con. Wisdom, 2(7), 95-102.

Kochatkov, A. (1994). Zapadnye ucheniya o grazhdanskom obshchestve (Western doctrines about civil society, in Russian). Vestnik Moskovskogo universta (Bulletin of the Moscow University, in Russian), 2, 69-78.

Kolesnikova, N. (2013). Modeli vzaimodeistviya organov gosudarstvennoi vlasti i struktur grazhdanskogo obshchestva (Models of interaction between public authorities and civil society structures, in Russian). Vestnik Moskovskogo universiteta upravleniya (Bulletin of the State University of Management, in Russian), 21, 270-276.

Kolesnikova, N., \& Ryabova, Y. (2016). Grazhdanskoe obshchestvo $\mathrm{v}$ sovremennoi Rossii (Civil society in contemporary Russia, in Russian). Moscow: International Publishing Center "Ethnosocium".

Lagutkin, A., Trubnikov, V., \& Grudtsyna, L. (2013). Grazhdanskoe obshchestvo v sovremennoi Rossii (Civil society in modern Russia, in Russian). Moscow: YURKOMPANI.

Marchenko, M. (2014). Pravovoe gosudarstvo i grazhdanskoe obshchestvo: teoretiko pravovoye issledovaniye (Legal state and civil society: Theoretical and legal research, in Russian) Textbook. Moscow: Prospect.

Marzik, G. (2013). K voprosu o vzaimodeistvii grazhdanskogo obshchestva i pravovogo gosudarstva (On the issue of interaction between civil society and the rule of law, in Russian). Novyy yuridicheskiy zhurnal (New Legal Journal, in Russian), 3, 11-16.

Mikhalkin, N. (2019). Filosofiya dlya yuristov (Philosophy for lawyers, in Russian). Moscow: Yurayt Publishing House.

O'Brien, R. (1999). Philosophical history of the idea of civil society. Retrieved from https://web.net/ robrien/papers/civhist. htmlv

Ryabev, V. (2005). K voprosu o vzaimodeistvii gosudarstva i grazhdanskogo obshchestva v sovremennoi Rossii (On the issue of interaction between the state and civil society in modern Russia, in Russian). Zhurnal sotsiologii $i$ sotsial'noi antropologii (Journal of Sociology and Social Anthropology, in Russian), 8(2), 5-21.

Smolkov, V. (1991). Problemy formirovaniya grazhdanskogo obshchestva (Problems of the formation of civil society, in Russian). Sotsial'no-politicheskie nauki (Socio-Political Sciences, in Russian), 4, 8-11.

Volkov, D. (2011). Rost obshchestvennoi aktivnosti v Rossii: stanovlenie grazhdanskogo obshchestva ili ocherednoi tupik? (Growth of public activity in Russia: The formation of civil society, in Russian). Vestnik obshchestvennogo mneniya: Dannyye. Analiz Diskussii (Public Opinion Bulletin: Data. Analysis. Discussions, in Russian), 8(2), 8-28. 